\title{
KAJIAN PENGEMBANGAN KEBIJAKAN PELAYANAN TERPADU SATU PINTU (PTSP) MELALUI PERSPEKTIF INDIKATOR KINERJA UTAMA (IKU)
}

\author{
Development Policy Review The One Stop Service (OSS) \\ Perspectives On Key Performance Indicators (KPI)
}

\author{
Abdul Halik \\ Badan Penelitian dan Pengembangan Kementerian Dalam Negeri \\ Jalan Kramat Raya No. 132 Jakarta Pusat \\ E-mail: liknph@yahoo.com
}

Dikirim: 13 Januari 2014; direvisi: 20 Januari 2014; disetujui: 12 Februari 2014

\begin{abstract}
Abstrak
Salah satu solusi untuk dapat mengatasi beberapa permasalahan PTSP adalah dengan menetapkan dimensi atau Komponen Kinerja Utama (KKU) dan Indikator Kinerja Utama (IKU) instansi PTSP. IKU ini merupakan ukuran keberhasilan instansi PTSP. Namun, hingga saat ini belum ada rumusan yang baku dan formal mengenai IKU untuk instansi PTSP yang dapat dijadikan rujukan untuk mengukur kinerja instansi tersebut. Padahal, dalam rangka pelaksanaan reformasi birokrasi di seluruh Kementerian/Lembaga/ Pemerintah Daerah, perlu disusun IKU. Tujuan kajian ini adalah untuk merumuskan atau menyusun KKU dan IKU instansi PTSP yang baku, sebagai acuan dalam pengukuran kinerja atau keberhasilan instansi PTSP. Kajian ini menggunakan pendekatan penelitian deskriptif. Hasil kajian ini merumuskan sejumlah dimensi/komponen kinerja utama (KKU) instansi PTSP, yaitu: kualitas struktur dan kewenangan, kualitas prosedur operasional pelayanan, kualitas proses perizinan, tingkat kepuasan pelayanan, tingkat perubahan investasi, tingkat perubahan PAD, dan tingkat perubahan PDRB. Hasil kajian ini kiranya dapat dijadikan bahan masukan atau referensi bagi Kementerian Dalam Negeri dalam merumuskan dan menyusun Peraturan Menteri Dalam Negeri (Permendagri) tentang Pedoman Pengukuran dan Penilaian Kinerja Instansi PTSP.

Kata kunci: penilaian, kinerja utama, perizinan, terpadu.
\end{abstract}

\begin{abstract}
One solution to overcome some of the problems of the OSS is to set the dimensions or Key Performance Component (KPC) and Key Performance Indicators (KPI) OSS agencies. This KPI is a measure of the success of the OSS agency. However, until now there is no standard formula and a formal OSS KPI for agencies that can be used as a reference to measure the performance of the agency. In fact, in the framework of bureaucratic reforms across Ministries/Institutions/Local Government, need to be prepared KPI. The purpose of this study is to formulate or construct KPI and standardized OSS KPI agencies, as a reference in measuring the performance or success of the OSS agency. The study used a descriptive research approach. The results of this study to formulate a number of dimensions/ key performance components (TPI) OSS agencies, namely: the quality and authority structures, operational procedures quality of service, the quality of the licensing process, the level of service satisfaction, the rate of change of investment, the rate of change of the Local Revenue, and the rate of change in GDP. The results of this study would be used as an input or reference to the Interior Ministry in the formulation and regulation of the Minister of Home Affairs (Permendagri) on Guidelines for Performance Measurement and Assessment Agencies OSS.

Keywords: assessment, the main performance, licensing, integrated.
\end{abstract}

\section{PENDAHULUAN}

Pelayanan merupakan wujud dari fungsi pemerintah sebagai bukti pengabdian kepada masyarakat. Rendahnya kualitas pelayanan di Indonesia selama ini mendorong pemerintah untuk segera memperbaiki kualitas pelayanannya, apalagi yang berhubungan dengan pelayanan perizinan yang dicitrakan sebagai pelayanan yang berbelit-belit, sulit diakses, memiliki prosedur yang sangat rumit, tidak adanya kepastian waktu, serta kurangnya keterbukaan biaya pelayanan yang dibutuhkan.
Dalam hal penyediaan pelayanan perizinan, petugas birokrasi seringkali memberikan prosedur yang sangat rumit dan cenderung berbelit-belit, dan jika mekanisme yang rumit itu terus tetap berjalan, maka akan masyarakat malas atau enggan mengurus perizinan. Atas dasar ini, maka pemerintah menginstruksikan kepada seluruh kepala daerah agar dapat segera menerapkan pola pelayanan perizinan terpadu satu pintu melalui Permendagri No. 24 Tahun 2006 tentang Pedoman Penyelenggaraan Perizinan Terpadu Satu Pintu (PTSP). Jenis kelembagaan PTSP diserahkan kepada daerah untuk memilih jenis lembaga yang sesuai, apakah berbentuk kantor atau 
badan yang disesuaikan dengan kemampuan dan kebutuhan daerah dalam mengelolanya. Dengan di bentuknya Kantor/Badan PTSP ini, sebagai institusi yang khusus bertugas memberikan pelayanan perizinan kepada masyarakat, maka masyarakat cukup mendatangi satu kantor/badan saja untuk mengurus izin.

Kebijakan pemerintah pusat melalui Permendagri No. 24/2006 tersebut diharapkan dapat menjadi kunci untuk mengurangi panjangnya birokrasi perizinan yang berpotensi terhadap penyelewengan. Kebijakan PTSP ini sebenarnya merupakan reformasi perizinan usaha yang dijalankan pemerintahan daerah. Sistem yang semula bernama One-Step Servive (OSS) dirancang untuk memperbaiki layanan perizinan berdasarkan Permendagri No. 24/2006 tentang Sistem Pelayanan Perizinan. Kemudian, untuk memaksimalkan UU No. 25/2009 tentang Pelayanan Publik, Presiden Susilo Bambang Yudhoyono (SBY) telah menandatangani PP No. 96/2012 tentang pelaksanaan UU tersebut. Peraturan ini merupakan bentuk penyempurnaan PSTP (http://www. okezone.com.).

Sistem pelayanan terpadu merupakan satu kesatuan proses pengelolaan pelayanan terhadap beberapa jenis pelayanan yang dilakukan secara terintegrasi dalam satu tempat, baik secara fisik maupun virtual (Pasal 14 Ayat 1 PP No. 96 Tahun 2012). Sistem pelayanan terpadu secara fisik itu bisa dalam bentuk sistem PTSP dan sistem Pelayanan Terpadu Satu Atap (PTSA). Penyelenggaraan PTSP adalah kegiatan penyelenggaraan perizinan dan non perizinan yang proses pengelolaannya mulai dari tahap permohonan sampai ke tahap terbitnya dokumen dilakukan dalam satu tempat. Dalam PTSP, kepala PTSP diberi pelimpahan kewenangan untuk menandatangani izin yang masuk, dan hal ini berarti penyederhanaan pelayanan. Penyederhanaan pelayanan adalah upaya peningkatan terhadap waktu, prosedur, dan biaya pemberian perizinan dan non perizinan. Perizinan adalah pemberian legalitas kepada seseorang atau pelaku usaha/kegiatan tertentu, baik dalam bentuk izin maupun tanda daftar usaha. Pemberlakuan PTSP ini diharapkan mampu memangkas waktu dan biaya yang dibutuhkan untuk mengurus perizinan. Hasilnya pelayanan perizinan lebih efektif, mudah, dan murah.

Memang, nampaknya masalah perizinan merupakan salah satu isu utama yang akan meningkatkan iklim usaha dan mendorong investasi swasta, baik domestik maupun asing, yang pada gilirannya nanti akan dapat menciptakan lapangan kerja dan meningkatkan pendapatan daerah. Diharapkan, pengurusan izin di daerah sudah sangat mudah dan transparan setelah daerah meluncurkan sistem PTSP. PTSP di bidang penanaman modal merupakan sistem penyederhanaan izin penanaman modal di daerah yang dibagi dalam 3 (tiga) paket, di Jakarta misalnya, proses perizinan selama 10 hari, 25 hari, dan 32 hari. Melalui PTSP ini, investor akan lebih dipermudah saat mengurus perizinan usaha. Sebab, PTSP mengintegrasikan titik penerimaan permohonan perizinan-perizinan dan non perizinan pada satu tempat.

Dengan proses seperti itu, selain dapat memperoleh informasi mengenai prosedur, waktu, dan biaya para investor, juga dapat mengajukan permohonan untuk memperoleh perizinan dan non perizinan hanya dalam satu langkah. Hal ini dilakukan juga sebagai tindak lanjut UU Penanaman Modal No. 25 Tahun 2007 untuk melayani pemrosesan investasi dan pengurusan lembaga bisnis dengan PTSP berbasis Teknologi Informasi.

Langkah tersebut merupakan pelayanan yang efisien, khususnya terhadap pelayanan perizinan, yang selama ini diakui sebagai proses yang berbelit dan panjang. Upaya ini merupakan solusi yang prima bagi masyarakat dan pemegang keputusan lainnya karena memiliki keunggulan yaitu cepat, mudah, transparan, bebas dari biaya tidak resmi, memiliki kepastian hukum, dan pelayanannya yang profesional.

Jadi, kondisi ideal yang diharapkan terjadi dari pelaksanaan sistem PTSP adalah aparatur pemerintah daerah memberikan perlindungan dan kepastian hukum kepada masyarakat, mendekatkan pelayanan kepada masyarakat, memperpendek proses pelayanan, mewujudkan proses pelayanan yang cepat, mudah, murah, transparan, pasti, terjangkau, serta memberikan akses yang lebih luas kepada masyarakat untuk memperoleh pelayanan. Dalam perspektif ini, maka salah satu indikator keberhasilan pelaksanaan pemerintahan daerah adalah kemampuan pemerintah daerah untuk memberikan pelayanan kepada publik dengan baik, dalam arti bahwa masyarakat memperoleh pelayanan secara mudah, murah, cepat, dan ramah, yang pada akhirnya mencapai ukuran kepuasan publik yang dikehendaki.

Namun, kondisi aktual yang terjadi, perlaksanaan kebijakan tersebut di atas masih menelurkan sejumlah masalah. Menurut Komite Pemantauan Pelaksanaan Otonomi Daerah (KPPOD), hingga kini kerangka aturan dari pusat malah tumpang tindih. Permasalahan perizinan usaha di daerah melalui sistem PTSP disebabkan prosedur birokrasi yang masih rawan korupsi dan percaloan. Selain itu, sistem PTSP belum mampu mengurangi biaya investasi dan lamanya waktu pengurusan izin. Bahkan, pelaksanaan PTSP di 100 kabupaten/kota tidak berjalan efektif. Dari jumlah tersebut, 77 di antaranya belum memenuhi aturan biaya yang disyaratkan dalam Permendagri No. 24 Tahun 2006. Temuan yang lainnya adalah adanya praktik pungutan siluman yang harus dibayar pengusaha dalam pengajuan sejumlah izin, di antaranya retribusi Surat Izin Usaha Perdagangan (SIUP) dan Tanda Daftar Perusahaan (TDP). Biaya SIUP dan TDP harusnya gratis, tetapi masih dipungut (Suara Tanah Air, 30 Januari 2012).

Di kota Makassar misalnya, penerapan PTSP terkendala ego sektoral (http://www.tibun- 
timur.com.). Idealnya, PTSP terkait perijinan dilakukan oleh KPAP, dan KPAP memiliki tim teknis yang merupakan perwakilan SKPD-SKPD teknis dan berkantor di KPAP. Wewenang terkait tim teknis sepenuhnya berada di bawah kepala KPAP. Dengan demikian, pemohon ijin hanya perlu berhadapan dengan front office KPAP dan tidak berurusan langsung dengan SKPD. Namun, ego sektoral menyebabkan setiap SKPD teknis menginginkan wewenang untuk memberikan rekomendasi tetap berada pada pihak mereka. Hal inilah yang menjadi salah satu barrier atau constraint yang terbesar implementasi PTSP di kota Maskassar. Di Provinsi Jambi, masih marak saol pungli. Di PTSP Jambi masih terjadi yang berkedok uang administrasi. Hal ini tentunya berdampak pada investor yang enggan berinvestasi, merusak nama baik daerah, pergerakan ekonomi akan lamban, sulit mewujudkan kesejahteraan rakyat, dan daerah akan lambat majunya (Hasil Rakor PTSP dan Bintek serta Sosialisasi Ketentuan Penanaman Modal di Jambi, 6 Maret 2012).

Peran PTSP dianggap pula belum maksimal sehingga permasalahan pokok yang dihadapi penanam modal dalam memulai usaha di Indonesia belum terselesaikan (http/www:detik.com.). Selain itu, ada juga kewenangannya diambil alih tingkat dinas. Padahal, seharusnya PTSP diberikan kewenangan lebih untuk mendapatkan izin mandiri guna memberikan kemudahan izin bagi perusahaan maupun investor yang ingin berinvestasi.

Hal yang lainnya adalah pengusaha susah berinvestasi, dan juga masih tumpang tindih dengan aturan pemerintah pusat dan aturan pemerintah daerah. Misalnya, ada penerapan perijinan dengan SIUP, di mana pusat sudah membebaskan iuran atau tidak perlu ada pembayaran apapun, namun berbeda dengan pemerintah daerah yang ternyata diperlukan pembayaran untuk kepentingan lain. Kelemahan PTSP yang lainnya adalah masalah pendelegasian, di mana selama ini masih ada $15 \%$ wilayah yang belum ada PTSP nya. Demikian pula, masih ada sejumlah pelayanan di Kantor Pelayanan Perizinan Terpadu (KPPT) justru diselesaikan di luar KPPT. Dalam pengurusan perizinan belum satu pintu karena masih harus keluar ke unit kerja lain yang terkait.

Di samping itu, sejumlah daerah pun memberlakukan biaya syarat tambahan di luar aturan yang ditetapkan oleh pemerintah pusat, dengan argumen untuk mengisi kantong Pendapatan Asli Daerah (PAD). Ini adalah salah satu problem otonomi daerah, di mana pemerintah daerah masih menganggap bahwa PTSP adalah pemasukan terbesar untuk menyumbang PAD. Di Kalimantan misalnya, izin lokasi yang harusnya tidak masuk persyaratan, ternyata masih dipungut, sehingga bisa mencapai sekitar Rp. 10 miliar untuk satu izin (Digdawiseiso, 2012).

Praktik korupsi tersebut di atas mengindikasikan ketiadaan visi dan komitmen dari pejabat daerah setempat. Permasalahan ini disebabkan tidak adanya Standard Operational Procedure (SOP) tentang reward and punishment bagi aparat PTSP. Selain itu, rekrutmen aparat pun dilakukan dari pihak di luar Satuan Kerja Perangkat Daerah (SKPD) dinas yang terkait. Masalah PTSP juga berkaitan dengan praktiknya yang belum maksimal dan masih memerlukan peningkatan lebih lanjut (The Asia Foundation, 2012). Selain itu, persoalan juga terkait dengan rendahnya insentif. Kondisi ini tentunya berimbas pada kewenangan dan koordinasi PTSP yang masih lemah. Kepala instansi pemerintah yang terlibat dalam PTSP menjalankan otoritas untuk kepentingan sendiri sehingga tidak mendelegasikan otoritas kepada bawahan atau instansi lain. Pengusaha datang ke PTSP direkomendasikan SKPD yang bersangkutan atau dinas-dinas. Ini hanya perantara saja. Ujungnya akan kembali lagi ke dinas.

Dalam kaitannya dengan investasi, penanaman modal (investasi) sangat vital bagi pertumbuhan dan percepatan pembangunan ekonomi di suatu negara/ daerah. Modal tersebut dapat digunakan sebagai alat untuk memulihkan perekonomian, menciptakan lapangan kerja, dan mengurangi kemiskinan. Demikian juga di Indonesia. pasca kebijakan desentralisasi Tahun 1999, banyak sekali pemerintah daerah yang bereksperiman dan berinovasi dengan mengembangkan berbagai pola pelayanan perizinan dan investasi. Namun demikian, terdapat banyak kendala untuk dapat menggali modal dari para penanam modal (investor). Secara umum, kendala tersebut dapat diinventarisir yang antara lain: (1) regulasi pemerintah yang tidak konsisten dan akomodatif sehingga cenderung membingungkan penanam modal dan calon penanam modal, (2) pelayanan perizinan yang tidak bisa diprediksi, lambat, dan tidak transparan, (3) kondisi politik dan keamanan dalam negeri yang belum memadai dan belum bisa diprediksi, (4) belum adanya jaminan kepastian hukum atas kontrak-kontrak yang telah disepakati pengusaha, terutama yang terkait dengan perusahaan asing, (5) peranan perbankan nasional dalam menyalurkan kredit ke sektor riil belum berfungsi secara normal, dan (6) pelaksanaan otonomi daerah belum memiliki arah yang jelas serta cenderung menciptakan pemerintahan baru di tingkat yang lebih rendah.

Dari berbagai kendala di atas, pelayanan perizinan merupakan kendala yang paling kasat mata. Studi yang pernah dilakukan Bank Dunia tahun 2011 menunjukkan bahwa birokrasi di Indonesia sangat rumit, dimulai dari prosedur untuk memulai penanaman modal baru, pengurusan perizinan, pertanahan, ekspor-impor, sampai dengan pengurusan pembayaran pajak. Untuk memulai suatu usaha di Indonesia, membutuhkan 12 prosedur yang memakan waktu 97 hari dengan biaya 86,7\% dari pendapatan per kapita penduduk Indonesia. Dibandingkan negaranegara tetangga, di Thailand misalnya, hanya butuh 8 prosedur yang memakan waktu hanya 33 hari dan 
biaya hanya 5,8\% dari pendapatan per kapita. Adapun di Malaysia, hanya membutuhkan 9 prosedur, 30 hari, dan $19,7 \%$ pendapatan per kapita untuk memulai usaha. Birokrasi dengan prosedur dan dokumen yang rumit ini pada akhirnya berakibat pada waktu yang terbuang dan biaya yang besar (http/www:detik.com).

Terkait dengan kondisi itu, maka pelaksanaan PTSP di daerah-daerah dinilai perlu direvitalisasi (Investor Daily Indonesia, 16 Desember 2011). Sebab, daerah yang telah menerapkan PTSP sebanyak 420 lebih, namun setelah disurvei, hanya sedikit yang benar-benar berjalan sesuai dengan fungsinya, yakni memberikan pelayanan dalam satu pintu yang efisien dan efektif. Masih banyak "jendela bolong” sana-sini. Perlu membenahi yang bolong-bolong itu, yaitu melakukan enforcement dan juga membenahi sistem. Revitalisasi PTSP dan penguatan peran serta kinerjanya telah masuk dalam program kerja Kementerian Pendayagunaan Aparatur Negara dan RB 2012. Di samping itu, perlu juga memperkuat monitoring dan evaluasi serta bekerja sama dengan Kementerian Dalam Negeri untuk melakukan pengawasan. Untuk daerah-daerah yang belum menyelenggarakan PTSP ppada Tahun 2011, Kemenpan perlu mendorong agar daerah yang bersangkutan segera menerapkan PTSP pada 2012.

Salah satu "solusi" untuk dapat mengatasi beberapa permasalahan PTSP yang telah dipaparkan di atas adalah dengan menetapkan dimensi/komponen kinerja utama dan Indikator Kinerja Utama (IKU) intansi PTSP. Dimensi/ Komponen Kinerja Utama (KKU) dan IKU ini merupakan ukuran keberhasilan instansi PTSP. Dalam rangka pengukuran dan peningkatan kinerja serta lebih meningkatkan akuntabilitas kinerja instansi PTSP, maka perlu menetapkan dimensi/komponen kinerja utama dan IKU PTSP yang baku. Perlu ditentukan apa yang menjadi kinerja utama dari instansi PTSP (kinerja utama adalah hal apa yang akan diwujudkan oleh instansi PTSP, atau untuk mewujudkan apa instansi PTSP di bentuk, yang menjadi core area/business dan tertuang dalam tugas dan fungsi serta kewenangan utama instansi PTSP). Dengan demikian, kinerja utama terkandung dalam tujuan dan sasaran strategis instansi PTSP, sehingga dimensi/komponen kinerja utama dan IKU adalah merupakan ukuran keberhasilan dari tujuan dan sasaran strategis instansi PTSP. Dengan kata lain, dimensi/komponen kinerja utama dan IKU digunakan sebagai ukuran keberhasilan dari instansi PTSP.

Hingga saat ini belum ada rumusan yang baku mengenai dimensi/ komponen kinerja utama dan IKU untuk instansi PTSP yang dapat dijadikan rujukan untuk mengukur kinerja instansi tersebut. Padahal, dalam rangka pelaksanaan reformasi birokrasi di seluruh Kementerian/Lembaga/ Pemerintah Daerah, perlu disusun dimensi/komponen kinerja utama dan IKU. Hal ini dilandasi dari kerangka pembangunan good governance, di mana kebijakan umum pemerintah adalah ingin menjalankan pemerintahan yang berorientasi pada hasil (result oriented government). Orientasi pada input, terutama uang, seperti selama ini dijalankan, hendaknya ditinggalkan. Pemerintahan yang berorientasi pada hasil pertamatama akan fokus pada kemaslahatan bagi masyarakat, berupa upaya untuk menghasilkan output dan outcome yang sesuai dengan kebutuhan masyarakat.

Output merupakan hasil langsung dari program-program atau kegiatan yang dijalankan pemerintah dan dapat berwujud sarana, barang, dan jasa pelayanan kepada masyarakat, sedangkan outcome adalah berfungsinya sarana, barang, dan jasa tersebut sehingga memberikan manfaat bagi masyarakat. Output dan outcome inilah yang selayaknya dipandang sebagai performance (kinerja), bukan kemampuan menyerap anggaran seperti persepsi yang ada selama ini (Framework for Managing Programme Performance Information, 2007). Akan tetapi, uang tetap merupakan faktor penting untuk mencapai kinerja tertentu berupa baik output maupun outcome. "Money follows function", bukan sebaliknya, karena itu prinsip dasar manajemen berbasis kinerja adalah "no performance, no money".

Berdasarkan hal di atas, maka sistem akuntabilitas kinerja instansi pemerintah, seperti instansi PTSP, perlu dibangun dan terus dikembangkan dalam rangka upaya mewujudkan good governance dan sekaligus result oriented government, termasuk informasi kinerja PTSP diintegrasikan ke dalam sistem penganggaran dan pelaporan. Dengan demikian, anggaran yang diharapkan adalah anggaran berbasis kinerja, yaitu anggaran yang dihitung dan disusun berdasarkan perencanaan kinerja instansi PTSP. Atau, dihitung dan disusun berdasarkan kebutuhan untuk menghasilkan output dan outcome instansi PTSP yang diinginkan masyarakat. Dengan anggaran berbasis kinerja ini, akan dapat dilakukan penelusuran alokasi anggaran ke kinerja instansi PTSP yang direncanakan, dan pada setiap akhir tahun anggaran juga dapat dilakukan penelusuran realisasi anggaran dengan capaian kinerja instansi PTSP. Hal ini akan memudahkan evaluasi instansi PTSP untuk mengetahui cost efficency dan cost effectiveness anggaran instansi PTSP, sekaligus memudahkan pencegahan dan deteksi kebocoran anggaran.

Salah satu upaya untuk memperkuat akuntabilitas dalam kerangka penerapan tata pemerintahan yang baik di Indonesia adalah telah dikeluarkan Peraturan Menteri Negara Pendayagunaan Aparatur Negara Nomor: PER/09/ M.PAN/5/2007, Tanggal 31 Mei 2007, tentang Pedoman Umum Penetapan Indikator Kinerja Utama (IKU) di Lingkungan Instansi Pemerintah. Berdasarkan regulasi tersebut, dimensi/komponen kinerja utama dan Indikator Kinerja Utama (IKU) atau Key Performance Indicators $(K P I)$ adalah ukuran keberhasilan dari suatu tujuan dan sasaran strategis organisasi. Setiap instansi Pemerintah, termasuk instansi PTSP, wajib menetapkan dimensi/komponen kinerja utama dan IKU untuk tujuan dan sasaran strategis untuk masing- 
masing tingkatan (level) secara berjenjang. Dimensi/komponen kinerja utama dan IKU instansi pemerintah (termasuk instansi PTSP) harus selaras antar tingkatan unit organisasi yang meliputi indikator kinerja keluaran (output) dan hasil (outcome).

Urgensi ditetapkan indikator-indikator kinerja instansi PTSP adalah agar terdapat proses yang wajar yang digunakan oleh para pelaksana dan pimpinan dalam mengelola usaha-usaha organisasi instansi PTSP guna mencapai hasil atau berkinerja tinggi. Logika pentingnya indikator kinerja instansi PTSP ini dapat dijelaskan mulai dari pentingnya pengukuran kinerja sampai pada hal-hal yang rinci dalam mengelola organisasi PTSP secara umum agar berjalan efektif dan efisien.

Jika aparat instansi PTSP tidak dapat mengukur apakah kegiatan dan programnya berhasil atau kinerja baik, maka aparat tersebut tidak memahami kegiatan atau programnya sendiri. Jika tidak paham/mengerti, maka tidak bisa mengendalikannya. Jika tidak bisa mengendalikannya, maka tentunya tidak bisa memperbaikinya. Lebih lanjut, jika aparat instansi PTSP tidak dapat mendemonstrasikan hasil dan kinerjanya, maka tentunya tidak dapat berkomunikasi dengan para stakeholder nya secara baik, termasuk tidak dapat menjelaskan nilai yang dapat diciptakan dari uang rakyat yang dibelanjakan untuk kegiatan PTSP.

Hal-hal yang lebih rinci lagi, jika aparat intansi PTSP tidak mengukur kinerja dan hasil kegiatan PTSP, maka tentunya tidak bisa membedakan apakah instansi tersebut berhasil atau gagal, tidak bisa belajar darinya, tidak bisa menghargai keberhasilan dan mempertahankan keberhasilan, dan bahkan mungkin memberi penghargaan kepada kegagalan, serta mungkin lebih parah lagi mengulangi kesalahan yang sama berkali-kali dan memboroskan sumberdaya.

Di sisi lain, jika aparat instansi PTSP dapat mengukur kinerja intansinya, maka tentunya dapat mengetahui banyak hal, seperti: (a) dapat memberi penghargaan kepada yang berhasil, (b) dapat mengetahui biaya sebenarnya, (c) dapat menghubungkan antara biaya dan hasil, (d) dapat menentukan apakah lebih baik dikerjakan sendiri atau perlu outsourcing, (e) dapat meningkatkan kinerja, dan (f) dapat memilih alternatif terbaik. Singkatnya, jika aparat instansi PTSP dapat mengukur kinerjanya, maka akan dapat mengerjakan tugas-tugasnya secara baik dan lebih berhasil. Jadi secara konseptual, indikator kinerja instansi PTSP adalah alat penting dalam membangun sistem pengukuran kinerja instansi PTSP. Pengukuran kinerja instansi PTSP dilakukan untuk mengelola kinerja agar organisasi PTSP dapat mencapai hasil yang baik dan kinerja yang tinggi.

Uraian-uraian di atas merupakan argumen rasionalitas "kemengapaan" pentingnya dikaji atau disusun dimensi/komponen kinerja utama dan IKU instansi PTSP dan selanjutkan dibakukan. Sebab, dengan di tetapkannya dimensi/ komponen kinerja utama dan IKU yang baku dalam lembaga pemerintah
PTSP, diharapkan akan diperoleh informasi kinerja instansi PTSP yang penting dan diperlukan dalam menyelenggarakan manajemen kinerja instansi tersebut secara baik, serta di perolehnya ukuran keberhasilan dari pencapaian tujuan dan sasaran strategis organisasi PTSP yang digunakan untuk perbaikan kinerja dan peningkatan akuntabilitas kinerja instansi PTSP.

Rumusan masalah kajian ini adalah "Bagaimana rumusan Komponen Kinerja Utama (KKU) dan Indikator Kinerja Utama (IKU) instansi PTSP yang baku?" Tujuan kajian ini adalah untuk merumuskan atau menyusun KKU dan IKU instansi PTSP yang baku, sebagai acuan dalam pengukuran kinerja atau keberhasilan instansi PTSP.

Untuk menjawab rumusan masalah di atas diperlukan acuan teoretik atau konseptual. Adapun acuan teoretik kajian ini adalah PTSP yang mencakup batasan PTSP, penyederhanaan pelayanan, tujuan PTSP, dan sasaran PTSP; serta IKU yang mencakup indikator, kinerja, kinerja utama, indikator kinerja, perbedaan kinerja yang akan diukur dengan indikator kinerja, Indikator Kinerja Utama (IKU), serta jenisjenis indikator kinerja (kinerja input, kinerja process, kinerja output, kinerja outcome, dan kinerja impact).

Penyederhanaan penyelenggaraan pelayanan didasarkan pada Penyelenggaraan PTSP (PPTSP). PPTSP adalah kegiatan penyelenggaraan perizinan dan non perizinan yang proses pengelolaannya mulai dari tahap permohonan sampai ke tahap terbitnya dokumen dilakukan dalam satu tempat.

Kinerja menekankan apa yang dihasilkan dari fungsi-fungsi suatu pekerjaan atau apa yang keluar, yaitu output, outcome, dan impact (Accounts Commision for Scotland, 2006). Bila disimak lebih lanjut apa yang terjadi dalam sebuah pekerjaan atan jabatan adalah suatu proses yang mengolah input menjadi output (hasil kerja), outcome, dan impact melalui suatu process yang baik. Penggunaan indikator kunci untuk mengukur hasil kinerja individu, bersumber dari fungsi-fungsi yang diterjemahkan dalam kegiatan/tindakan dengan landasan standar yang jelas dan tertulis (Lapsley, Irvine dan Falconer Mitchell, 2006). Mengingat kinerja mengandung komponen kompetensi dan produktivitas hasil, maka hasil kinerja sangat tergantung pada tingkat kemampuan individu dalam pencapaiannya (Center for Economic and Social Studies, 2006).

KPI singkatan bahasa Inggris: Key Performance Indicators), atau Indikator Kinerja Utama (IKU) dalam bahasa Indonesia, adalah metrik finansial ataupun non-finansial yang digunakan untuk membantu suatu organisasi menentukan dan mengukur kemajuan terhadap sasaran organisasi (GCIS. 2003). KPI digunakan dalam intelijen bisnis untuk menilai keadaan kini suatu bisnis dan menentukan suatu tindakan terhadap keadaan tersebut. $K P I$ sering digunakan untuk menilai aktivitas-aktivitas yang sulit diukur seperti keuntungan pengembangan kepemimpinan, perjanjian, layanan, dan kepuasan. 
KPI umumnya dikaitkan dengan strategi organisasi yang contohnya diterapkan oleh teknik-teknik seperti kartu skor berimbang (Asian Foundation. 2007). KPI berbeda tergantung sifat dan strategi organisasi. KPI merupakan bagian kunci suatu sasaran terukur yang terdiri dari arahan, $K P I$, tolok ukur, target, serta kerangka waktu. Sebagai contoh, "meningkatkan pendapatan rata-rata per pelanggan dari 10 ribu ke 15 ribu rupiah pada akhir tahun 2008" (Epstein, Marc J. and Bill Bichard, 2009). Dalam contoh ini, 'pendapatan rata-rata per pelanggan' adalah suatu KPI.

Indikator Kinerja Utama (IKU) atau Key performance indicators (KPI) dapat diartikan sebagai ukuran atau indikator yang akan memberikan informasi sejauh mana kita telah berhasil mewujudkan sasaran strategis yang telah kita tetapkan (Green. 2012). Instansi pemerintah sebagai lembaga pelayanan publik berkewajiban menyusun IKU sebagai suatu ukuran atau patokan keberhasilan kinerja organisasi. Dengan adanya rumusan indikator bagi keberhasilan organisasi maka berdasarkan ketercapaian indikator tersebut dilakukan pengukuran kinerja organisasi, yang akan menjelaskan tingkat kemajuan kinerja organisasi dalam memberikan pelayanan kepada masyarakat.

Adapun kerangka pemikiran/alur pikir kajian ini dapat digambarkan secara skematis seperti skema pada Gambar 1.

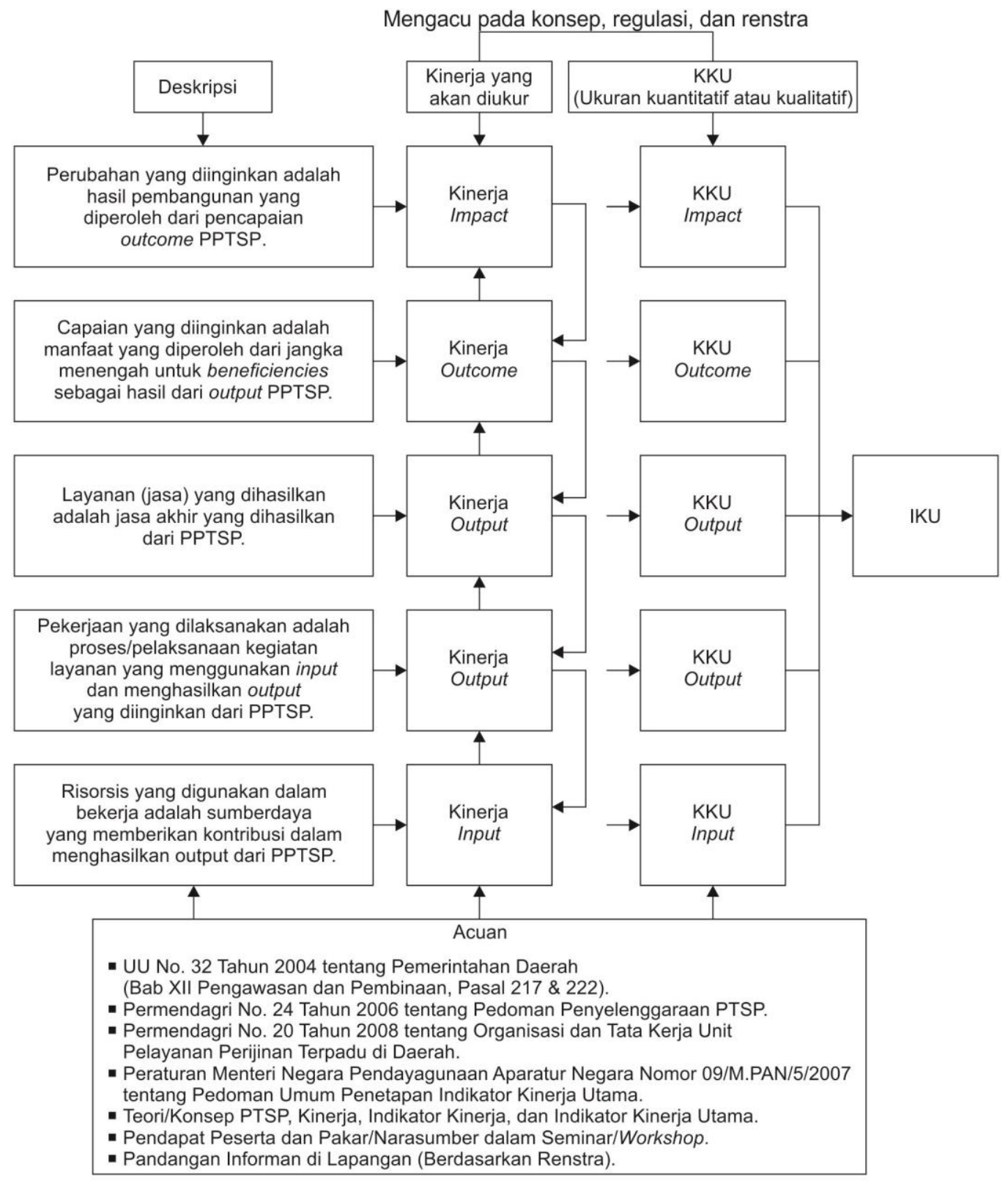

Gambar 1. Kerangka Penyusunan KKU dan IKU Instansi PTSP 


\section{METODE PENELITIAN}

Kajian ini menggunakan pendekatan penelitian desktiptif. Menurut Whitney (2000), penelitian deskriptif adalah pencarian fakta dengan interpretasi yang tepat. Eksplanasi secara deskriptif dalam kajian ini adalah membuat deskripsi atau gambaran secara sistematis, faktual, dan akurat mengenai fakta-fakta empiris yang berkaitan dengan kinerja instansi PTSP. Fakta-fakta kinerja instansi PTSP yang dimaksud adalah fakta kinerja input, process, output, outcome, dan impact dari instansi PTSP, yang didalam pelaksanaan tugas dan fungsi instansi tersebut mengacu pada RPJMD dan Rensta SKPD PTSP . Fakta-fakta yang ditemukan di lapangan akan ditafsirkan dengan tepat, dan selanjutnya menjadi dasar dalam penyusunan atau perumusan dimensi/komponen kinerja utama dan IKU PTSP yang baku.

\section{Lokasi}

Lokasi kajian ini adalah di daerah Provinsi Jawa Barat, Provinsi Jawa Tengah, dan Provinsi D.I. Yogyakarta. Pertimbangan pemilihan lokasi ini terutama karena di daerah-daerah tersebut telah terbentuk instansi PTSP.

\section{Waktu dan Pelaksanaan}

Kajian ini dilaksanakan selama 6 (enam) bulan, yaitu dari bulan April sampai dengan bulan September 2013.

\section{Syarat, Kriteria, Penyusunan, dan Pengukuran Kinerja PTSP}

Pertama, syarat-syarat penetapan rancangan rumusan dimensi/komponen kinerja utama dan IKU instansi PTSP adalah: (1) Relevan, yaitu indikator kinerja instansi PTSP harus berhubungan dengan apa yang diukur dan secara objektif dapat digunakan untuk pengambilan keputusan atau kesimpulan tentang pencapaian apa yang diukur, (2) Penting/menjadi prioritas dan harus berguna untuk menunjukkan keberhasilan, kemajuan, atau pencapaian (accomplishment) hasil dari instansi PTSP, dan (3) Efektif dan layak, yaitu data/informasi yang berkaitan dengan indikator kinerja instansi PTSP dapat dikumpulkan, diolah, dan dianalisis dengan biaya yang layak.

Kedua, kriteria penetapan rancangan rumusan dimensi/komponen kinerja utama dan IKU intansi PTSP adalah: (1) Spesifik, yaitu indikator kinerja intansi PTSP harus sesuai dengan program dan atau kegiatan sehingga mudah dipahami dalam memberikan informasi yang tepat tentang hasil atau capaian kinerja dari kegiatan dan atau sasaran PTSP; (2) Dapat dicapai, yaitu indikator kinerja intansi PTSP yang ditetapkan harus menantang namun bukan hal yang mustahil untuk dicapai dan dalam kendali instansi PTSP; (3) Relevan, yaitu indikator kinerja intansi PTSP harus dapat mengukur sedekat mungkin dengan hasil yang akan diukur; (4) Menggambarkan sesuatu yang diukur, yaitu indikator kinerja intansi PTSP merupakan ukuran dari suatu keberhasilan instansi PTSP; dan (5) Dapat dikuantifikasi dan diukur, yaitu indikator kinerja intansi PTSP dalam angka (jumlah atau persentase nilai dolar, tonase, dsb.) atau dapat diukur untuk dapat ditentukan kapan dapat dicapai, sedangkan indikator kualitatif adalah indikator yang bersifat pengamatan deskriptif.

Ketiga, langkah-langkah (tahapan) penetapan rancangan rumusan dimensi/ komponen kinerja utama dan IKU intansi PTSP adalah: (1) Melakukan klarifikasi apa yang menjadi kinerja utama instansi PTSP, termasuk pernyataan hasil (result statement) atau tujuan/sasaran yang ingin capai dari instansi PTSP; (2) Menyusun daftar awal IKU instansi PTSP yang mungkin dapat digunakan (setelah mengidentifikasikan kebutuhan-kebutuhan akan informasi kinerja dan kewajiban-kewajiban pelaporan akuntabilitas instansi PTSP). Dalam menyusun daftar awal indikator kinerja instansi PTSP, dilakukan halhal sebagai berikut: (a) Brainstorming internal oleh tim surveyor, (b) Konsultasi dengan para ahli di bidang pelayanan perijinan (melalui $F G D$ ), dan (c) Menggunakan pengalaman pihak lain dengan kegiatan yang sama atau sejenis; (3) Melakukan evaluasi atau penilaian setiap dimensi/komponen kinerja utama dan IKU PTSP yang terdapat dalam daftar awal indikator kinerja instansi PTSP; dan (4) Memilih dimensi/komponen kinerja utama dan IKU instansi PTSP. Dalam pemilihan harus selektif. Pilihlah indikator kinerja yang dapat mewakili dimensi yang paling mendasar dan penting dari setiap tujuan/sasaran instansi PTSP.

Keempat, rancangan rumusan indikatorindikator kinerja instansi PTSP yang telah ditetapkan diukur secara: (1) kualitatif, yaitu menggunakan skala (misal: baik, cukup, kurang), (2) kuantitatif absolut, yaitu menggunakan angka absolut (misal: 30 orang, 80 unit), (3) persentase, yaitu menggunakan perbandingan angka absolut dari yg diukur dengan populasinya (misal: 50\%, 100\%), (4) rasio, yaitu membandingkan angka absolut dengan angka absolut lain yang terkait (misal: rasio jumlah aparat PTSP dibandingkan jumlah aparat Pemda secara keseluruhan), (5) rata-rata, yaitu angka rata-rata dari suatu populasi atau total kejadian (misal: rata-rata biaya pelatihan per peserta dalam suatu Diklat bidang pelayanan perizinan), dan (6) indeks, yaitu angka patokan dari beberapa variabel kejadian berdasarkan suatu rumus tertentu (misal: indeks kepuasan masyarakat).

\section{Teknik Pengumpulan Data}

Pengumpulan data kinerja dalam kajian ini mengunakan teknik: (1) dokumentasi, dan (2) wawancara. Ada 2 (dua) jenis data yang dikumpulkan, yaitu data primer dan data sekunder. Data kinerja primer instansi PTSP adalah data kinerja instansi PTSP yang diperoleh langsung dari informan kajian 
ini. Data primer ini dikumpulkan oleh surveyor kajian ini melalui interviu. Adapun data kinerja sekunder instansi PTSP adalah data kinerja instansi PTSP yang diperoleh secara tidak langsung dari informan kajian ini, tetapi dari pihak/instansi lain yang berkompeten dengan pelayanan perijinan terpadu, atau catatancatatan pelaksanaan kegiatan instansi PTSP beserta hasilnya dalam bentuk dokumen. Jika data tidak dapat dipenuhi dari sistem informasi yang ada pada instansi, maka perlu dilakukan survai untuk mendapatkan data dari luar instansi.

\section{Instrumen}

Sesuai dengan kedua teknik pengumpulan data yang digunakan di atas, maka instrumen (alat) kajian atau alat pengumpulan data yang dipakai dalam dalam ini adalah: (1) ceklis dokumen, dan (2) pedoman wawancara terbuka. (instrumen kajian ini terlampir).

\section{Informan}

Informan dalam kajian ini adalah aparat instansi Penyelenggara Pelayanan Terpadu Satu Pintu (PPTSP).

\section{Teknik Analisis Data}

Analisis data dalam kajian ini menggunakan teknik deskriptif. Setelah data terkumpul, maka lalu diklasifikasikan menjadi 2 (dua) kelompok data, yaitu data kualitatif dan data kuantitatif. Terhadap data yang bersifat kualitatif (yang dihimpun melalui wawancara), yaitu yang digambarkan dengan katakata atau kalimat, dipisah-pisahkan menurut kategori untuk memperoleh kesimpulan. Adapun data yang bersifat kuantitatif (yang dihimpun melalui dokumentasi), yang berwujud angka-angka, diproses dengan cara dihitung, dijumlahkan, atau dipersentasekan, dan kemudian dideskripsikan.

\section{HASIL DAN PEMBAHASAN}

\section{Hasil}

Pertama, Provinsi Daerah Istimewa Yogyakarta merupakan salah satu dari 33 provinsi di wilayah Indonesia, terletak di Pulau Jawa bagian tengah. DIY di bagian selatan dibatasi Lautan Indonesia, sedangkan di bagian timur laut, tenggara, barat, dan barat laut dibatasi oleh wilayah provinsi Jawa Tengah yang meliputi: Kabupaten Klaten di sebelah Timur Laut, Kabupaten Wonogiri di sebelah Tenggara, Kabupaten Purworejo di sebelah Barat, dan Kabupaten Magelang di sebelah Barat Laut. Provinsi Daerah Istimewa Yogyakarta terdiri atas empat kabupaten dan satu kota dengan 78 kecamatan dan 438 desa/kelurahan, dengan perincian: (1) Kota Yogyakarta terdiri atas 14 kecamatan dan 45 kelurahan/desa; (2) Kabupaten Bantul terdiri atas 17 kecamatan dan 75 kelurahan/desa; (3) Kabupaten Kulon Progo terdiri atas 12 kecamatan, 1 kelurahan dan 87desa; (4) Kabupaten Sleman terdiri atas 17 kecamatan dan 86 kelurahan/desa; dan (5) Kabupaten
Gunungkidul terdiri atas 18 kecamatan dan 144 kelurahan/desa.

Posisi Daerah Istimewa Yogyakarta yang terletak antara $7^{\circ} 33^{\prime}-8^{\circ} 12^{\prime}$ Lintang Selatan dan $110^{\circ} 00^{\prime}-110^{\circ} 50^{\prime}$ Bujur Timur, tercatat memiliki luas $3.185,80 \mathrm{~km}^{2}$ atau $0,17 \%$ dari luas Indonesia $\left(1.860 .359,67 \mathrm{~km}^{2}\right)$. DIY merupakan provinsi terkecil setelah Provinsi DKI Jakarta, yang terdiri atas: (1) Kota Yogyakarta, dengan luas 32,50 km² (1,02\%); (2) Kabupaten Bantul, dengan luas 506,85 km² (15,91\%); (3) Kabupaten Kulon Progo, dengan luas $586,27 \mathrm{~km}^{2}$ (18,40\%); (4) Kabupaten Sleman, dengan luas 574,82 $\mathrm{km}^{2}$ (18,04\%); dan (5) Kabupaten Gunungkidul, dengan luas 1.485,36 km² (46,63\%).

Jumlah penduduk DIY pada tahun 2011 menurut hasil proyeksi SP 2010 BPS sebanyak 3.467.200 jiwa dengan komposisi penduduk laki-laki sebanyak 1.740.900 jiwa dan perempuan sebanyak 1.726.300 jiwa. Laju pertumbuhan penduduk DIY pada tahun 2011 sebesar 1,02. Dua daerah di Provinsi DIY masih memiliki laju pertumbuhan penduduk yang relatif tinggi yaitu Kabupaten Sleman $(1,92 \%)$ dan Kabupaten Bantul (1,55\%). Laju pertumbuhan penduduk tiga daerah lainnya memiliki laju pertumbuhan penduduk yang relatif rendah yaitu Kota Yogyakarta $(-0,22 \%)$, Kabupaten Gunungkidul $(0,06 \%)$ dan Kabupaten Kulon Progo (0,47\%).

Dinas Perizinan Kota Yogyakarta merupakan salah satu PTSP di Indonesia yang yang sejak pembentukannya telah mengalami berbagai kemajuan dan prestasi yang diraih. Diantaranya adalah berdasarkan penilaian oleh Worldwide Qualifty Assurance, Dinas Perizinan Kota Yogyakarta berhak menerima Sertifikat ISO 9001:2008. Kemudian penelitian skala global, International Finance Corporation (IFC) dalam laporan survey Doing Business 2011 yang dirilis tahun 2012. Survei dilakukan di 20 kota di Indonesia dan 183 perekonomian. Kota Yogyakarta menempati peringkat ke empat dunia dalam survei kemudahan mendirikan usaha.

Dalam rangka peningkatan pelayanan kepada masyarakat berdasarkan SE Mendagri No. 503/125/PUOD Tahun 1997 perihal Pembentukan Unit Pelayanan Terpadu Perijinan di Daerah, Pemerintah Kota Yogyakarta membentuk Unit Pelayanan Terpadu Satu Atap dengan Keputusan Walikota Yogyakarta No.01 Tahun 2000 tentang Pembentukan Unit Pelayanan Terpadu Satu Atap (UPTSA) Kota Yogyakarta. Lembaga UPTSA tersebut masih merupakan front office, sedangkan untuk proses perizinannya tetap di instansi/SKPD teknis. Untuk operasional UPTSA, ditunjuk koordinator UPTSA yang diberikan tunjangan daerah disetarakan dengan eselon IIIB, sekretaris UPTSA disetarakan dengan Eselon IVB. Jenis pelayanan yang ada di UPTSA pada saat itu antara lain; Akta Capil, HO, TDI, TDG, SIUP, IMBB, SAL, SAK, In-gang, IPPT, IPL dan sewa alat berat. 
Selanjutnya berdasar PP No.8 Tahun 2003 tentang Pedoman Organisasi Perangkat Daerah, Pemerintah Kota Yogyakarta membentuk lembaga pelayanan perizinan yang definitif berupa Dinas Perizinan (hingga sekarang). Selanjutnya Dinas Perijinan itu sendiri berdiri pada 15 November tahun 2005. Dasar hukum pembentukan Dinas Perizinan tersebut adalah Peraturan Daerah (Perda) Kota Yogyakarta No. 17 Tahun 2005 tentang Pembentukan, Organisasi dan Tata Kerja Dinas Perizinan.

Keberadaan Dinas Perizinan Kota Yogyakarta ini tersedia di pusat kota, dengan akses yang mudah dijangkau oleh masyarakat dan kendaraan umum. Dan lokasinya berada di sekitar kelompok instansi/unit teknis, karena memang seluruh SKPD di Pemerintah Kota Yogyakarta terdapat pada satu komplek terpadu.

Kedua, Provinsi Jawa Tengah. Jawa Tengah sebagai provinsi dibentuk sejak zaman Hindia Belanda. Hingga tahun 1905, Jawa Tengah terdiri atas 5 wilayah (gewesten) yakni Semarang, Kudus, Kedu, Banyumas, dan Pekalongan. Surakarta masih merupakan daerah swapraja kerajaan (vorstenland) yang berdiri sendiri dan terdiri dari dua wilayah, Kasunanan Surakarta dan Mangkunegaran, sebagaimana Yogyakarta. Masing-masing gewest terdiri atas kabupaten-kabupaten. Waktu itu Kudus Gewest juga meliputi Regentschap Tuban dan Bojonegoro. Setelah di berlakukannya Decentralisatie Besluit tahun 1905, gewesten diberi otonomi dan dibentuk Dewan Daerah.

Selain itu juga dibentukgemeente (kotapraja) yang otonom, yaitu Pekalongan, Tegal, Semarang, Salatiga, dan Magelang. Sejak tahun 1930, provinsi ditetapkan sebagai daerah otonom yang juga memiliki Dewan Provinsi (Provinciale Raad). Provinsi terdiri atas beberapa kepresidenan (residentie), yang meliputi beberapa kabupaten (regentschap), dan dibagi lagi dalam beberapa kawedanan (district). Provinsi Jawa Tengah terdiri atas 5 karesidenan, yaitu: Pekalongan, Kudus-Rembang, Semarang, Banyumas, dan Kedu. Menyusul kemerdekaan Indonesia, pada tahun 1946 Pemerintah membentuk daerah swapraja Kasunanan dan Mangkunegaran; dan dijadikan karesidenan. Pada tahun 1950 melalui Undang-undang ditetapkan pembentukan kabupaten dan kotamadya di Jawa Tengah yang meliputi 29 kabupaten dan 6 kotamadya. Penetapan Undang-undang tersebut hingga kini diperingati sebagai Hari Jadi Provinsi Jawa Tengah, yakni tanggal 15 Agustus 1950.

Secara administratif, Provinsi Jawa Tengah terdiri atas 29 kabupaten dan 6 kota. Administrasi pemerintahan kabupaten dan kota ini terdiri atas 545 kecamatan dan 8.490 desa/kelurahan. Sebelum diberlakukannya Undang-undang Nomor 22/1999 tentang Pemerintahan Daerah, Jawa Tengah juga terdiri atas 3 kota administratif, yaitu Kota Purwokerto, Kota Cilacap, dan Kota Klaten. Namun sejak diberlakukannya Otonomi Daerah tahun 2001 kota-kota administratif tersebut dihapus dan menjadi bagian dalam wilayah kabupaten. Menyusul otonomi daerah, 3 kabupaten memindahkan pusat pemerintahan ke wilayahnya sendiri, yaitu Kabupaten Magelang (dari Kota Magelangke Mungkid), Kabupaten Tegal (dari Kota Tegal ke Slawi), serta Kabupaten Pekalongan (dari Kota Pekalongan ke Kajen).

Jumlah penduduk Provinsi Jawa Tengah adalah 32.380.687 jiwa terdiri atas 16.081.140 laki-laki dan 16.299.547 perempuan. Kabupaten/kota dengan jumlah penduduk terbesar adalah Kabupaten Brebes (1,732 juta jiwa), Kabupaten Cilacap (1,644 juta jiwa), dan Kabupaten Banyumas (1,553 juta jiwa). Sebaran penduduk umumnya terkonsentrasi di pusat-pusat kota, baik kabupaten ataupun kota. Kawasan permukiman yang cukup padat berada di daerah Semarang Raya (termasuk Ungaran dan sebagian wilayah Kabupaten Demak dan Kendal), daerah Salatiga Raya ( termasuk wilayah Ambarawa, Bringin, Kopeng, Tengaran dan Suruh), Solo Raya (termasuk sebagian wilayah Kabupaten Karanganyar, Sukoharjo, dan Boyolali), serta Tegal-Brebes-Slawi. Pertumbuhan penduduk Provinsi Jawa Tengah sebesar $0,67 \%$ per tahun. Pertumbuhan penduduk tertinggi berada di Kabupaten Demak (1,5\% per tahun), sedang yang terendah adalah Kota Pekalongan $(0,09 \%$ per tahun). Dari jumlah penduduk ini, $47 \%$ di antaranya merupakan angkatan kerja. Mata pencaharian paling banyak adalah di sektor pertanian $(42,34 \%)$, diikuti dengan perdagangan $(20,91 \%)$, industri $(15,71 \%)$, dan jasa $(10,98 \%)$.

Dengan di tetapkannya: (1) Peratuan Daerah kota Semarang Nomor 2008 tahun 2008 tentang Organisasai dan Tata Kerja Lembaga Teknis Daerah dan Badan Pelayanan Perijinan Terpadu Kota Semarang; (2) Keputusan Walikota Semarang Nopmor 875.1/2 Tahun 2011 tentang pendelegasian wewenang penandatanganan perijinan dan non perijinan kepada Kepala Badan Pelayanan Perijinan Terpadu Kota Semarang; (3) Peraturan Walikota Semarang Nomor 1 A Tahun 2011 tentang Hubungan kerja BPPT dengan Dinas Daerah dilingkungan pemeriontahan kota Semarang; dan (4) Keputusan Walikota Semarang Nomor 875.1/000255 tentang Pendelegasian wewenang penandatanganan perijinan penanaman modal kepada Kepala BPPT kota Semarang, maka penyelenggaraan pelayanan perijinan terpadu dilaksanakan oleh Badan Pelayanan Perijinan Terpadu Kota Semarang.

Maksud Penetapan Pelayanan Perijinan Terpadu di Jawa Tengah yaitu: (1) Terwujudnya pelayanan perijinan yang tepat, mudah, transparan, dan memberikan kepastian hukum; (2) Terwujudnya hak-hak masyarakat dan penanam modal untuk mendapatkan pelayanan dibidang perijinan; dan (3) Menciptakan citra pelayanan prima di kota Semarang.

Badan Pelayanan Perijinan Terpadu adalah unsur pelayanan masyarakat di bidang perijinan dan non perijinan yang berkedudukan di bawah dan bertanggung jawab kepada Walikota melalui Sekretaris Daerah (PerdaNo.13 Tahun 2008). Salah 
satu tugas Pemerintah yang sekaligus juga hak dari warga adalah terselenggaranya pelayanan publik perijinan merupakan wujud pelayanan publik yang sangat menonjol dalam tata pemerintahan.

Relasi antara pemerintah dan warganya seringkali perijinan menjadi indikator untuk menilai apakah sebuah tata pemerintahan sudah mencapai kondisi "Good Governance" atau belum. Birokrasi Perijinan merupakan salah satu permasalahan yang menjadi kendala bagi perkembangan dunia usaha di Indonesia pada umumnya dan khususnya di Jawa Tengah. Masyarakat dan kalangan dunia usaha sering mengeluhkan proses pelayanan perijinan oleh pemerintah yang tidak memiliki kejelasan prosedur, berbelit-belit, tidak transparan, waktu pemrosesan ijin yang tidak pasti, dan tingginya biaya yang harus dikeluarkan terutama berkaitan dengan biaya-biaya tidak resmi.

Pemerintah melalui Departemen Dalam Negeri (sekarang Kemendagri) menindak lanjuti Instruksi Presiden No. 3 Tahun 2006 tentang paket kebijakan perbaikan iklim Invastasi dengan meluncurkan kebijakan yang dituangkan dalam Peraturan Menteri Dalam Negeri No. 24 Tahun 2006 tentang pedoman penyelenggaraan pelayanan terpadu satu pintu. Pelayanan Perijinan Terpadu yang merupakan pelayanan publik yang meliputi semua jenis perijinan dan non perijinan yang menjadi kewenangan Pemerintah kota Semarang berdasarkan Peraturan Perundang-undangan yang berlaku.

BPPT kota Semarang memiliki 30 jenis perijinan dan non perijinan, terdiri dari (1) Bidang perijinan pembangunan sebanyak 9 perijinan; (2) Bidang perijinan perekonomian sebanyak 10 perijinan; dan (3) Bidang perijinan kesra sebanyak 11 perijinan.

Ketiga, Provinsi Jawa Barat. Provinsi Jawa Barat, secara geografis, terletak pada posisi $5^{\circ} 50^{\prime}$ $7^{\circ} 50^{\prime}$ Lintang Selatan dan $104^{\circ} 48^{\prime}-108^{\circ} 48^{\prime}$ Bujur Timur, dengan batas wilayah yaitu: (1) Sebelah utara: Laut Jawa dan Provinsi DKI Jakarta; (2) Sebelah timur: Provinsi Jawa Tengah; (3) Sebelah selatan: Samudra Indonesia; dan (4) Sebelah barat: Provinsi Banten. Luas wilayah Jawa Barat adalah 37.116,54 $\mathrm{km}^{2}$. Kabupaten Sukabumi merupakan wilayah terluas di Jawa Barat sebesar 4.160,75 $\mathrm{km}^{2}$ atau sebesar $11,21 \%$ dari luas wilayah Jawa Barat. Adapun luas wilayah terkecil adalah Kota Cirebon dan Cimahi masing-masing sebesar $40,16 \mathrm{~km}^{2}$ dan $41,2 \mathrm{~km}^{2}$ atau sebesar 0,11\% dari luas wilayah Jawa Barat.

Selanjutnya, penduduk merupakan salah satu modal dalam pelaksanaan pembangunan karena penduduk merupakan objek sekaligus subjek dalam pembangunan. Berdasarkan data yang ada, Provinsi Jawa Barat dihuni sebanyak 43.021.826 jiwa (Sumber: Bappeda Provinsi Jawa Barat, 2013). Secara nasional Jawa Barat masih merupakan provinsi dengan jumlah populasi terbesar dibanding dengan provinsi lain di Indonesia. Hal tersebut dapat dilihat berdasarkan tiga daerah dengan penduduk terbesar yaitu: Kabupaten
Bogor 4.763.209 jiwa, Kabupaten Bandung 3.174.499 jiwa dan Kabupaten Bekasi 2.629.551 jiwa. Adapun tiga daerah dengan penduduk terkecil yaitu: Kota Banjar 175.165 jiwa, Kota Cirebon 295.764 jiwa dan Kota Sukabumi 299.247 jiwa.

Adanya ketidak merataan penduduk di Provinsi Jawa Barat disebabkan kondisi dan potensi diri di setiap kabupaten tidak sama. Kepadatan penduduk yang tinggi cenderung terjadi di kabupaten dan daerah perkotaan dimana banyak terdapat kegiatan-kegiatan ekonomi masyarakat di berbagai bidang usaha yang dapat memberikan lapangan pekerjaan. Penduduk yang telah memasuki usia kerja didefinisikan sebagai penduduk yang berusia limabelas tahun keatas yang terdiri dari angkatan kerja (bekerja dan mencari kerja) dan bukan angkatan kerja (sekolah, mengurus rumah tangga, dan lainnya). Pada tahun 2010, jumlah angkatan kerja di Provinsi Jawa Barat sebanyak 18.240.036 orang dan jumlah angkatan bukan kerja sebanyak 10.944.744 orang. Tetapi pada tahun 2012 terjadi peningkatan jumlah angkatan kerja sebanyak 18.981.260 orang dan jumlah angkatan bukan kerja sebanyak 11.200.929 orang. Penduduk Provinsi Jawa Barat pada tahun 2012 rata-rata masih bekerja di sektor pertanian yaitu sebanyak 26,97\% kemudian rata-rata penduduk yang bekerja di sektor perdagangan sebanyak 24,79\%. Adapun penduduk yang bekerja di sektor industri rata-rata sebanyak $16,93 \%$.

Latar belakang pembentukan Badan Pelayanan Perijinan Terpadu (BPPT) Provinsi Jawa Barat didasari oleh adanya komitmen Pemerintah Provinsi Jawa Baratdalam rangka reformasi birokrasi pelayanan publik di Jawa Barat. BPPT Provinsi Jawa Barat dalam rangka meningkatkan kualitas pelayanan publik di bidang perijinan telah dilaksanakan pelayanan perijinan secara terpadu sesuai kewenangan Pemerintah Provinsi Jawa Barat. Maka, pada bulan Julitahun 2007 dibentuklah Unit Pengelola Pelayanan Terpadu Satu Pintu yang telah melaksanakan pelayanan perijinan di wilayah provinsi Jawa Barat sebanyak 111 jenis perijinan meliputi 59 jenis layanan ijin dan 52 jenis layanan non ijin.

Badan Pelayanan Perijinan Terpadu (BPPT) Provinsi Jawa Barat sebelumnya memiliki nama Pelayanan Perijinan Terpadu Satu Pintu (PPTSP) Provinsi Jawa Barat yang merupakan suatu kegiatan penyelenggara perijinan yang proses pengelolaannya mulai dari tahap permohonan sampai ke tahap terbitnya dokumen hanya dilakukan dalam satu tempat.

Dengan di tetapkannya Peratuan Daerah Provinsi Jawa Barat Nomor 24 tahun 2008 tentang Organisasai dan Tata Kerja Lembaga Lain Provinsi Jawa Barat, maka penyelenggaraan pelayanan perijinan terpadu dilaksanakan oleh Badan Pelayanan Perijinan Terpadu Provinsi Jawa Barat. Pelaksanaan administratif PPTSP Provinsi Jawa Barat adalah Unit Pengelola Pelayanan Terpadu Satu Pintu (unit PPTSP) 
Tabel 2. Contoh Penilaian Kinerja Instansi PTSP

(Pengukuran Kinerja Jangka Pendek, Menengah, dan Panjang)

\begin{tabular}{lrrc}
\hline \multicolumn{1}{c}{$\begin{array}{c}\text { Dimensi/Komponen } \\
\text { Kinerja Utama (KKU) }\end{array}$} & $\begin{array}{c}\text { Skor } \\
\text { Ideal }\end{array}$ & $\begin{array}{c}\text { Skor } \\
\text { Aktual }\end{array}$ & $\begin{array}{c}\text { Persentase } \\
(\%)\end{array}$ \\
\hline $\begin{array}{l}\text { Kinerja Jangka Pendek: } \\
\text { 1. Kualitas Struktur dan Kewenangan }\end{array}$ & 180 & 140 & $77,78 \%$ \\
2. Kualitas Prosedur Operasional & 80 & 68 & $85,00 \%$ \\
$\quad$ Pelayanan & 286 & 196 & $68,53 \%$ \\
2. Kualitas Proses Perizinan & 100 & 73 & $73,00 \%$ \\
3. Tingkat Kepuasan Pelayanan & & & \\
Kinerja Jangka Menengah: & 30 & 15 & $50,00 \%$ \\
$\begin{array}{l}\text { 1. Tingkat Perubahan Investasi } \\
\text { 2. Tingkat Perubahan PAD }\end{array}$ & 15 & 5 & $66,33 \%$ \\
$\begin{array}{l}\text { Kinerja Jangka Panjang: } \\
\text { 1. Tingkat Perubahan PDRB } \\
\quad \text { Total }\end{array}$ & 30 & 20 & $71,71 \%$ \\
\hline
\end{tabular}

Sumber: Data Sekunder (Diolah).

Catatan:

- $\quad 140 / 180 \times 100=77,78 \%$, dst.

- $517 / 721$ X $100=71,71 \%$ (Tingkat Kinerja) tahun 2007 yang dikoordinasikan oleh BPPMD Provinsi Jawa Barat.

Maksud Penetapan Pelayanan Perijinan Terpadu di Jawa Barat yaitu: (1) Terwujudnya pelayanan perijinan yang tepat, mudah, transparan, dan memberikan kepastian hukum; (2) Terwujudnya hak-hak masyarakat dan penanam modal untuk mendapatkan pelayanan dibidang perijinan; dan (3) Menciptakan citra pelayanan prima di Jawa Barat.

Badan Pelayanan Perijinan Terpadu adalah unsur pelayanan masyarakat di bidang perijinan yang berkedudukan di bawah dan bertanggung jawab kepada Gubernur melalui Sekretaris Daerah (PerdaNo. 24 Tahun 2008). Salah satu tugas Pemerintah yang sekaligus juga hak dari warga adalah terselenggaranya pelayanan publik perijinan merupakan wujud pelayanan publik yang sangat menonjol dalam tata pemerintahan.

Relasi antara pemerintah dan warganya seringkali perijinan menjadi indikator untuk menilai apakah sebuah tata pemerintahan sudah mencapai kondisi "Good Governance" atau belum. Birokrasi Perijinan merupakan salah satu permasalahan yang menjadi kendala bagi perkembangan dunia usaha di Indonesia pada umumnya dan khususnya di Jawa Barat. Masyarakat dan kalangan dunia usaha sering mengeluhkan proses pelayanan perijinan oleh pemerintah yang tidak memiliki kejelasan prosedur, berbelit-belit, tidak transparan, waktu pemrosesan ijin yang tidak pasti, dan tingginya biaya yang harus dikeluarkan terutama berkaitan dengan biaya-biaya tidak resmi.

Pemerintah melalui Departemen Dalam Negeri (sekarang Kemendagri) menindak lanjuti Instruksi Presiden No. 3 Tahun 2006 tentang paket kebijakan perbaikan iklim Invastasi dengan meluncurkan kebijakan yang dituangkan dalam Peraturan Menteri Dalam Negeri No. 24 Tahun 2006 tentang pedoman penyelenggaraan pelayanan terpadu satu pintu. Pelayanan Perijinan Terpadu yang merupakan pelayanan publik yang meliputi semua jenis perijinan dan non perijinan yang menjadi kewenangan Pemerintah Provinsi Jawa Barat berdasarkan Peraturan Perundang yang berlaku.

BPPT Provinsi Jawa Barat memiliki 59 jenis dari layanan ijin sedangkan untuk layanan non ijinnya BPPT Provinsi Jawa Barat memiliki 52 jenis layanan non ijin dari masing-masing bidang perijinan. Layanan bidang perijinan yang paling banyak ijinnya adalah pada bidang perijinan perhubungan yaitu 12 jenis perijinan sedangkan untuk layanan non ijin bidang perijinan yang paling banyak adalah perijinan pada sub bidang peternakan.

\section{Pembahasan}

Ada 7 (tujuh) hasil rumus dimensi/Komponen Kinerja Utama (KKU) instansi PTSP dalam kajian ini, yaitu: (1) Kualitas Struktur dan Kewenangan (Kinerja Input - Jangka Pendek), (2) Kualitas Prosedur Operasional Pelayanan (Kinerja Process - Jangka Pendek), (3) Kualitas Proses Perizinan (Kinerja Process - Jangka Pendek), (4) Tingkat Kepuasan Pelayanan (Kinerja Output - Jangka Pendek), (5) Tingkat Perubahan Investasi (Kinerja Outcome Jangka Menengah), (6) Tingkat Perubahan PAD (Kinerja Outcome - Jangka Menengah), dan (7) Tingkat Perubahan PDRB (Kinerja Outcome - Jangka Panjang).

Penetapan ketujuh dimensi/komponen kinerja utama (KKU) instansi PTSP tersebut dilengkapi dengan skala/skor yang beragam pada setiap IKU nya sebagai acuan pengukuran, cara pengumpulan 
Tabel 3. Pedoman Penilaian Mutu dan Kinerja Instansi PTSP

\begin{tabular}{ccc}
\hline $\begin{array}{c}\text { Interval } \\
(\%)\end{array}$ & $\begin{array}{c}\text { Mutu } \\
\text { Pelayanan }\end{array}$ & Kinerja \\
Intansi PTSP \\
\hline$<40 \%$ & $\mathrm{D}$ & Tidak Baik \\
$40 \%-55 \%$ & $\mathrm{C}$ & Kurang Baik \\
$56 \%-75 \%$ & $\mathrm{~B}$ & Cukup \\
$76 \%-100 \%$ & $\mathrm{~A}$ & Baik \\
\hline
\end{tabular}

Sumber Acuan: Suharsimi Arikunto, 2009.

datanya, serta cara penilaian mutu pelayanan dan kinerja instansi PTSP dengan menggunakan parameter dimensi/komponen kinerja utama dan IKU intansi PTSP yang telah dirumuskan. Skala penilaian IKU PTSP yang digunakan adalah skala bebas, karena bentuk dan banyaknya IKU pada setiap KKU tidak sama. Skala bebas adalah skala yang tidak tetap, ada kalanya skor tertinggi 5, lain kali 6, lain laki 8, dan seterusnya. Jadi, angka/skor tertinggi dari skala yang di gunakan tidak selalu sama.

Dari sekian banyak acuan/masukan di atas, perlu "disederhanakan" atau dipilih beberapa Indikator Kinerja (IK) saja yang dipandang memang paling menentukan (strategis)/sesuai Renstra, yang mencerminkan keberhasilan/prestasi kerja instansi PTSP, serta spesifik bagi instansi PTSP untuk ditetapkan sebagai dimensi/komponen kinerja utama, indikator kinerja pokok, kunci, atau IKU intansi PTSP, seperti tertera dalam lampiran Tabel 1.

Skala penilaian IKU PTSP yang digunakan adalah skala bebas, karena bentuk dan banyaknya IKU pada setiap KKU tidak sama. Skala bebas adalah skala yang tidak tetap, ada kalanya skor tertinggi 5, lain kali 6 , lain kali 8, dan seterusnya. Jadi, skor tertinggi dari skala yang di gunakan tidak selalu sama.

Cara menilai kinerja instansi PTSP berdasarkan 7 (tujuh) dimensi/KKU dan 25 (dua puluh lima) IKU yang telah ditetapkan di atas adalah sebagai berikut: (1) Total skor aktual untuk setiap dimensi/komponen kinerja utama (ada 7) dipersentasekan, dengan cara total skor aktual dibagi dengan skor ideal (skor maksimal yang mungkin dicapai tiap dimensi/komponen kinerja utama) dikali 100; dan (2) Setelah itu, dijumlahkan total skor aktual dari 7 dimensi/komponen kinerja utama. Tingkat kinerja suatu intansi PTSP dapat diketahui dengan cara: total skor aktual dari 7 dimensi/komponen kinerja utama dibagi dengan total skor ideal (721) dikali 100.

\section{Instansi PTS X}

Pedoman untuk memberikan penilaian mutu dan kinerja suatu instansi PTSP terlihat pada Tabel 3

Dari contoh di atas (Tabel 3) dapat diketahui bahwa mutu pelayanan instansi PTSP $\mathrm{X}=\mathrm{B}$, artinya kinerja instansi PTSP $\mathrm{X}$ termasuk kategori Cukup $(71,71 \%)$.

\section{SIMPULAN}

Rumusan Komponen Kinerja Utama (KKU) instansi PTSP yang perlu dibakukan mencakup dimensi kualitas struktur dan kewenangan, kualitas prosedur operasional pelayanan, kualitas proses perizinan, tingkat kepuasan pelayanan, tingkat perubahan investasi, tingkat perubahan PAD, dan tingkat perubahan PDRB.

Indikator Kinerja Utama (IKU) dari KKU Kualitas Struktur dan Kewenangan mencakup: (a) Kualitas bentuk organisasi, (b) Kualitas dasar aturan pembentukan organisasi, (c) Kualitas derajad kewenangan, (d) Jumlah penanganan izin usaha utama, dan (e) Jumlah penanganan izin usaha lainnya. IKU dari KKU Kualitas Prosedur Operasional Pelayanan mencakup: (a) Ketersediaan Rencana Tertulis Strategi Pengembangan SDM, (b) Ketersediaan SOP, (c) Ketersediaan Laporan Periodik (termasuk Keuangan), (d) Kualitas Mekanisme Pembayaran, dan (e) Ketersediaan Infrastruktur IT. IKU dari KKU Kualitas Proses Perizinan mencakup: (a) Jumlah Dokumen dan Persyaratan Perizinan yang Dibutuhkan, (b) Persentase Penyimpangan Persyaratan Resmi, (c) Jumlah Permohonan yang Diproses Secara Paralel, (d) Jumlah Hari yang Diperlukan Untuk Proses Perizinan, (e) Persentase Pelayanan yang Paling Mendekati Waktu Resmi, (f) Biaya Perizinan yang Resmi, dan (g) Persentase Penyimpangan dari Biaya Resmi. IKU dari KKU Tingkat Kepuasan Pelayanan mencakup: (a) Persentase Pemohon Izin yang Memperoleh Informasi Layanan yang Diperlukan, (b) Kualitas Mekanisme Penyelesaian Keluhan (Kotak Saran, Telephone Hotline, E-mail/ Internet, SMS), dan (c) Rata-rata Laporan Pemohon Izin Tentang Mutu Penyelesaian Pengaduan. IKU Tingkat Perubahan Investasi adalah: (a) Persentase nilai investasi, dan (b) Persentase investor baru. IKU dari KKU Tingkat Perubahan PAD mencakup: (a) Persentase Nilai PAD. Adapun IKU dari KKU Tingkat Perubahan PDRB mencakup: (a) Jumlah/Banyaknya Izin yang Diterbitkan Terhadap PDRB, dan (b) Persentase Nilai PDRB.

Hasil kajian ini kiranya dapat dijadikan bahan masukan atau referensi bagi Kementerian Dalam Negeri dalam merumuskan dan menyusun Peraturan Menteri Dalam Negeri (Permendagri) tentang Pedoman Pengukuran dan Penilaian Kinerja Instansi PTSP. 


\section{DAFTAR PUSTAKA}

Accounts Commision for Scotland. 2006. Better Practice Principle for Performance Information. Australia: Australian National Audit Office.

Asian Foundation. 2007. Mengukur Kinerja Pelayanan Terpadu untuk Perizinan Usaha di Indonesia. Jakarta: AF.

Center for Economic and Social Studies. 2006. Methodology for Mapping Local Business Licensing Policy and Survey of One Stop Shop Service Centers. Jakarta: AF.

Digdawiseiso. 2012. Kasus Perizinan di Kalimanatan. Kalimantan: TII.

Epstein, Marc J. and Bill Bichard. 2009. Counting What Counts, Turning Corporate Accountability to Competitive Advantages. New York: Perseus Books, and Harper Collin Publisher.

Framework for managing programme performance information. 2007. National Treasure. Republic of South Africa.

GCIS. 2003. Performance Measurement for IS/IT Service. London: CCTA.

Green. 2012. Indikator Kinerja Utama (Terjemahan Moeheriono). Jakarta: RajaGrafindo Persada.

Investor Daily Indonesia. 2011, 16 Desember. Revitalisasi PTSP.

Lapsley, Irvine dan Falconer Mitchell. 2006. Accounting and Performance Measurement. London: Paul Chapman Publishing, Ltd.

Pemda Provinsi Jambi. 2012, 6 Maret. Hasil Rakor PTSP dan Bintek serta Sosialisasi Ketentuan Penanaman Modal di Jambi.

Penerapan PTSP di Makassar: http//www.tribuntimur.com. Diakses tanggal 30 Maret 2012.

Permasalahan Pelayanan Perizinan di Indonesia: http/www.detik.com. Diakses tanggal 9 November 2012.

Republik Indonesia. 2006. Permendagri No. 24 Tahun 2006 tentang Pedoman Penyelenggaraan PTSP.

\footnotetext{
----------. 2007. Peraturan Menteri Negara Pendayagunaan Aparatur Negara Nomor 09/M.PAN/5/2007 tentang Pedoman Umum Penetapan Indikator Kinerja Utama.

$\begin{array}{llr}\text { Pendayagunaan Aparatur } & \text { Menteri Negara } \\ \text { PER/20/MENPAN/11/2008 tentang Pedoman }\end{array}$ Penyusunan Indikator Utama Menteri Negara Pendayagunaan Aparatur Negara.

Sistem Pelayanan Perijinan: http://www.okezone.com. Diakses Tanggal 10 Dessember 2012.

Suara Tanah Air. 2012. 30 Januari. Permasalahan Perizinan Usaha di Daerah.
} 
Tabel 1. Penetapan Skala/Skor IKU Instansi PTSP

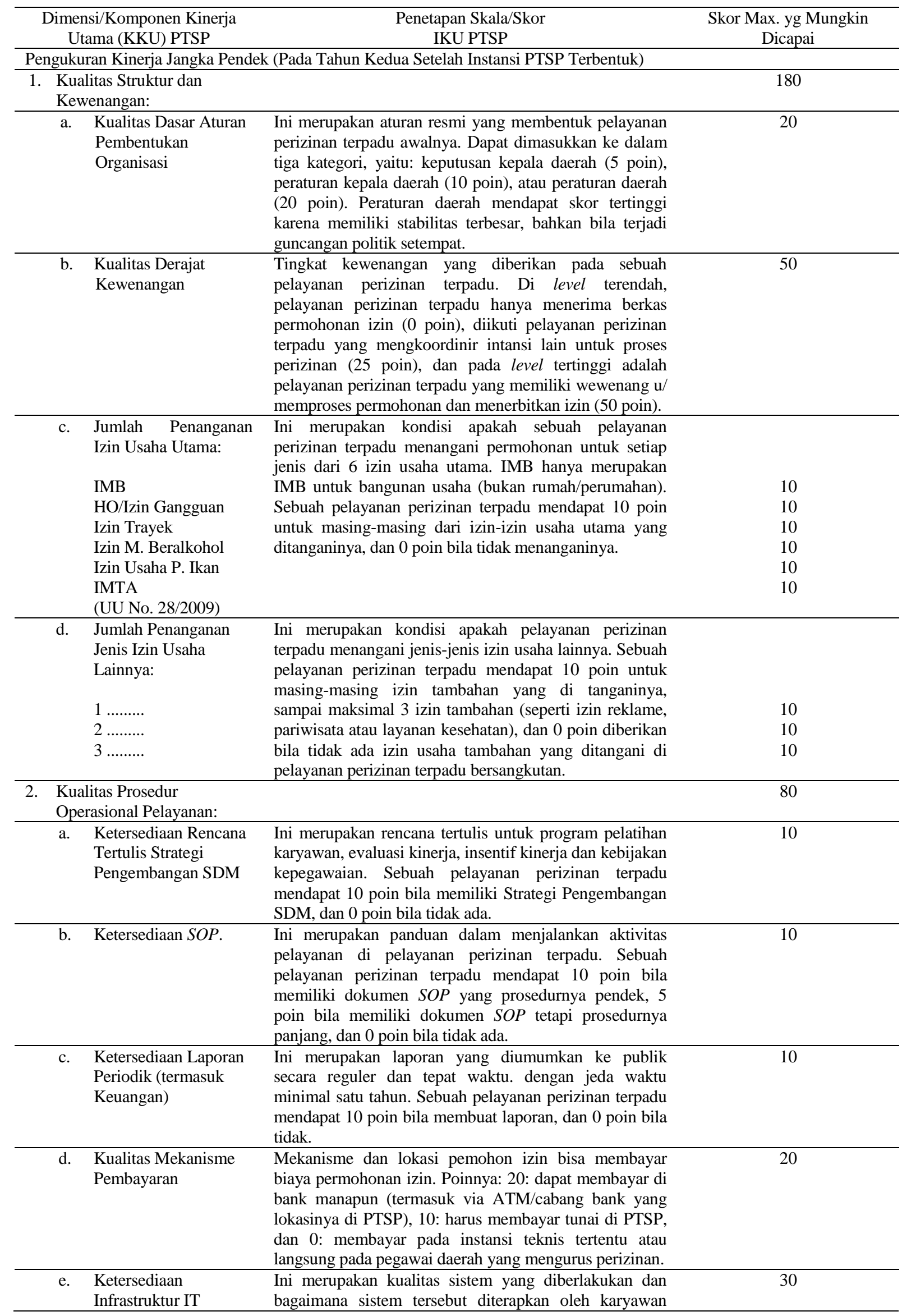




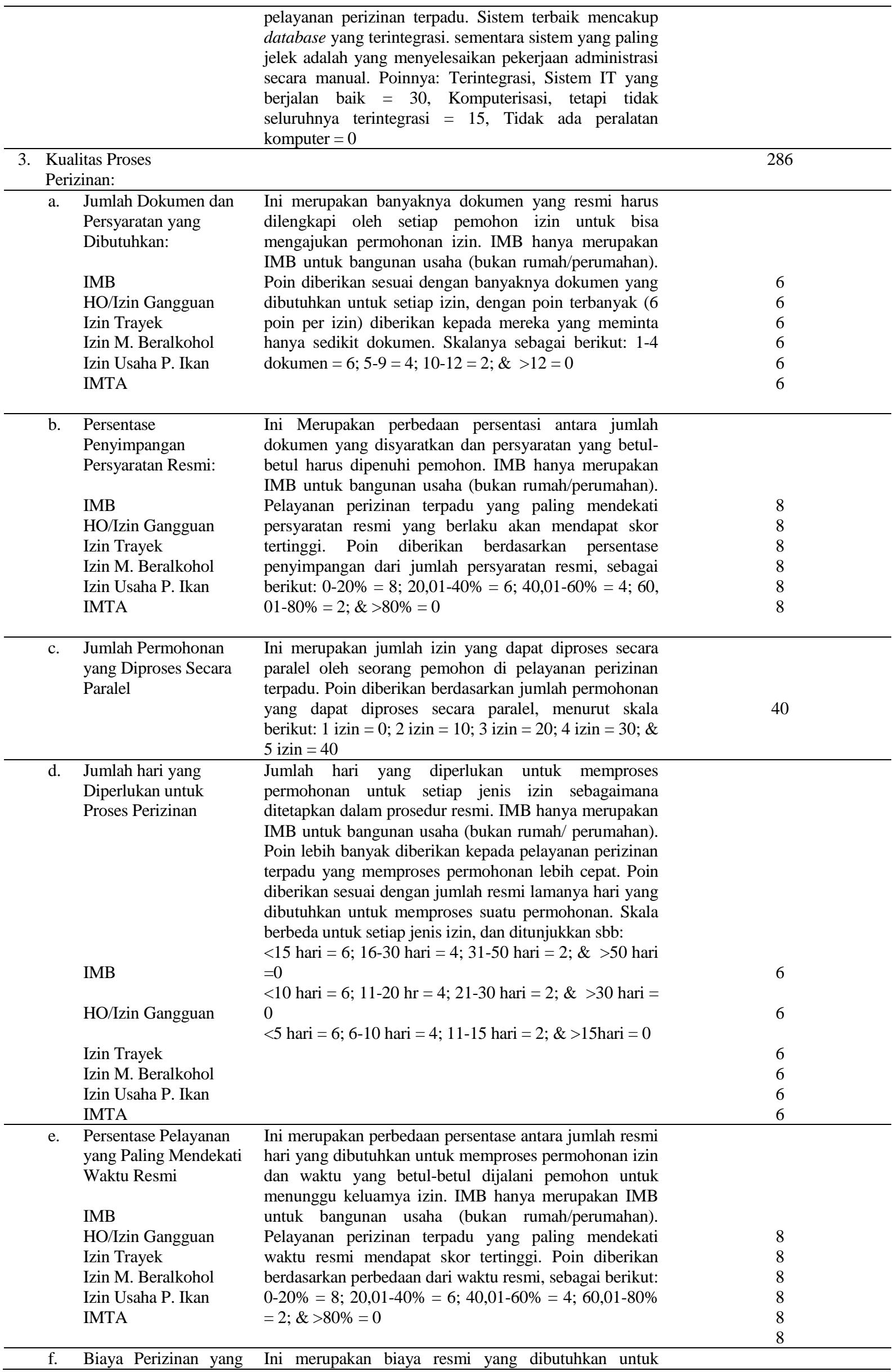




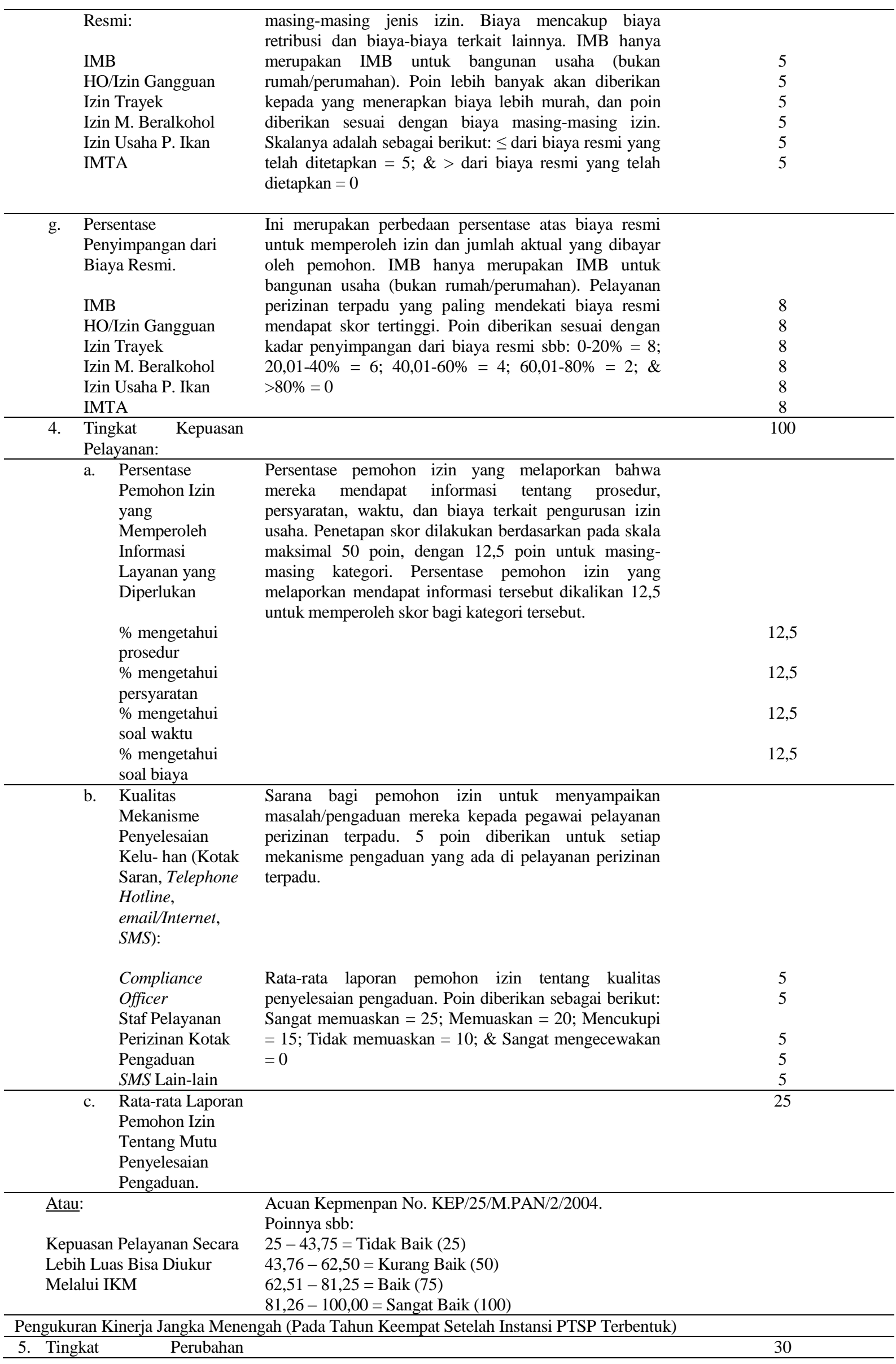




\begin{tabular}{|c|c|c|}
\hline \multicolumn{3}{|l|}{ Investasi: } \\
\hline $\begin{array}{l}\text { a. Persentase nilai Inves- } \\
\text { tasi }\end{array}$ & $\begin{array}{l}\text { Skor: peningkatan nilai investasi (dalam Rp.) dari tahun } \\
\text { sebelumnya } 1-40 \%=5 ; 40,01-80 \%=10 ; \&>80 \%=15 \text {. }\end{array}$ & 15 \\
\hline $\begin{array}{l}\text { b. Persentase Investor } \\
\text { Baru }\end{array}$ & $\begin{array}{l}\text { Skor: peningkatan jumlah investor (dalam jumlah } \\
\text { perusahaan) dari tahun sebelumnya } 1-40 \%=5 ; 40,01- \\
80 \%=10 ; \&>80 \%=15 \text {. }\end{array}$ & 15 \\
\hline $\begin{array}{l}\text { 6. Tingkat Perubahan } \\
\text { PAD: }\end{array}$ & & 15 \\
\hline $\begin{array}{l}\text { a. Persentase nilai } \\
\text { PAD. }\end{array}$ & $\begin{array}{l}\text { Skor: peningkatan PAD perizinan PTSP dari tahun } \\
\text { sebelumnya } 1-40 \%=5 ; 40,01-80 \%=10 ; \&>80 \%=15 .\end{array}$ & 15 \\
\hline \multicolumn{3}{|c|}{ Pengukuran Kinerja Jangka Panjang (Pada Tahun Keenam Setelah Instansi PTSP Terbentuk) } \\
\hline $\begin{array}{l}\text { 7. Tingkat Perubahan } \\
\text { PDRB: }\end{array}$ & & 30 \\
\hline $\begin{array}{ll}\text { a. } & \text { Jumlah/Banyaknya } \\
\text { Izin yang Diterbitkan } \\
\text { terhadap PDRB. }\end{array}$ & $\begin{array}{l}\text { Banyaknya (jumlah) izin utama yang diterbitkan dalam } \\
\text { setiap tahunnya dikaitkan dengan PDRB non-migas } \\
\text { kabupaten/kota yang dilayani pelayan- an perizinan } \\
\text { terpadu, dan diukur menurut level dollar di tahun } \\
\text { sekarang. Skor rasio jumlah izin yang terbit } \\
\text { dibandingkan jumlah aktivitas ekonomi/PDRB adalah: } \\
\text { kurang/sedikit }=5 \text {; sama }=10 ; \& \text { melampaui }=15\end{array}$ & 15 \\
\hline b. Persentase nilai PDRB. & $\begin{array}{l}\text { Skor: peningkatan PDRB dari tahun sebelumnya } 1-40 \% \\
=5 ; 40,01-80 \%=10 ; \&>80 \%=15 .\end{array}$ & 15 \\
\hline
\end{tabular}

Sumber: Data Sekunder (Diolah).

Catatan:

- Total skor ideal/maksimal yang mungkin dicapai: $180+80+286+100+30+15+30=721$.

- Untuk kelembagaan PTSP, jika perubahan regulasi telah mengatur bahwa seluruh kelembagaan PTSP adalah Badan, maka secara otomatis indikator kelembagaan yang masuk dalam rumusan IKU PTSP ini (IKU a pada KKU 1) tidak dapat digunakan lagi sebagai salah satu pengukuran kinerja PTSP. 
